\title{
Cover Crop, Rootstock, and Root Restriction Regulate Vegetative Growth of Cabernet Sauvignon in a Humid Environment
}

\author{
Tremain A. Hatch, ${ }^{1}$ Cain C. Hickey, ${ }^{1}$ and Tony K. Wolf ${ }^{1 *}$
}

\begin{abstract}
Cover crops, rootstocks, and root restriction were evaluated as means to regulate vegetative growth of Cabernet Sauvignon grapevines in a humid environment. Treatments were arranged as a strip-split-split plot with row-middle and under-trellis cover crop (UTCC) compared to row-middle only cover crop combined with $85 \mathrm{~cm}$ weed-free strips in the vine row as main plots. Rootstocks Riparia Gloire (Riparia), 420A, and 101-14 were subplots, while sub-subplots comprised two treatments: vines were either planted in root-restrictive (RR) fabric bags $\left(0.015 \mathrm{~m}^{3}\right)$ at vineyard establishment or were planted without root restriction. Root restriction and UTCC were independently effective in suppressing vegetative development as measured by rate and seasonal duration of shoot growth, lateral shoot development, trunk circumference, and dormant pruning weights. Riparia was the most effective rootstock in limiting vegetative development among the three evaluated; vines grafted to Riparia had $25 \%$ lower cane pruning weights than did vines grafted to $420 \mathrm{~A}$ or $101-14$. Under-trellis cover crop reduced cane pruning weights by $47 \%$ relative to vines grown on herbicide strips. Canopy architecture was generally improved by both UTCC and by root restriction, but generally unaffected by rootstock. Root restriction reduced the discrimination against ${ }^{13} \mathrm{C}$ assimilation in both berries and leaf laminae tissue as measured by $\delta^{13} \mathrm{C}$, while under-trellis floor management did not affect this measure of chronic water stress. The principal direct effect of the UTCC and the root-restriction treatments was a sustained reduction in stem (xylem) water potential $\left(\psi_{\text {stem }}\right)$. Stomatal conductance and net assimilation rate were depressed by increasing water deficit, particularly for root-restricted vines. Results suggest practical measures can be used to create a more favorable vine balance under conditions of variable rainfall, such as exist in the eastern United States.
\end{abstract}

Key words: canopy management, cover crops, rootstocks, root restriction, vine balance

Grapevines grown in the humid eastern United States frequently exhibit overly vigorous growth observed as seasonal persistence of shoot growth, strong lateral shoot development, increased canopy leaf layers, and cane pruning weights well in excess of $0.6 \mathrm{~kg} / \mathrm{m}$ of canopy, a provisional upper, optimal threshold (Smart and Robinson 1991). The consequences of excessive vegetative development are manifold and compounded when meteorological and ecological conditions favor disease development. Excessive canopy density can lead to fruit, leaf, and bud shading, which, in turn, can reduce fruit quality, increase disease intensity, and reduce fruitfulness in the current and subsequent year. Shaded fruit, relative to more fully exposed fruit, is often lower in anthocyanins, certain flavor and aroma compounds, sugar, and phenolics and may exhibit elevated titratable acidity and $\mathrm{pH}$ (Kliewer and Dokoozlian 2005, Smart et al. 1985).

\footnotetext{
${ }^{1}$ AHS Jr. Agricultural Research and Extension Center, Virginia Tech, 595 Laurel Grove Rd., Winchester, VA 22602.

*Corresponding author (email: vitis@vt.edu)

Acknowledgments: Funding for this research was provided by the Virginia Wine Board, the Virginia Agricultural Council, and the Viticulture Consortium:East.

The authors are grateful for the technical assistance of M. Miller, A. Johnson, L. Hickey, L. McIntire, B. Millholland, and K. Staats.

Manuscript submitted Jan 2011, revised Apr 2011, accepted Apr 2011

Copyright (C) 2011 by the American Society for Enology and Viticulture. All rights reserved.

doi: 10.5344/ajev.2011.11001
}

Although an "imbalanced" or high-vigor condition is not unique to the eastern United States, it is often exacerbated in humid regions. Supraoptimal plant available water (PAW) is a common feature of humid climates; PAW is a leading cause of excessive vegetative growth and contributes to reduced wine quality potential (Van Leeuwen and Seguin 1994, Van Leeuwen et al. 2009). Vineyard site evaluation should, but does not always, consider topographic and edaphic features that contribute to vine size and vigor, such as surface and internal water drainage, PAW, and effective rooting depth. Abundant soil moisture can retard budbreak, increase both the rate and duration of shoot growth, increase dormant pruning weight and increase berry weight with a concomitant decrease in berry sugar concentration, anthocyanins, and phenolic compounds (Chaves et al. 2007, Van Leeuwen and Seguin 1994, Van Leeuwen et al. 2009). Even with appropriate vineyard site assessment, regions that receive $75 \mathrm{~mm}$ or more rainfall per month of the growing season, as do many sites within the mid-Atlantic United States, still have the potential for excessive vegetative development. Therefore, a range of vine and vineyard management tools is often used to compensate for excessive growth. Canopy management options include shoot hedging, leaf and lateral shoot removal, modified training systems, and the use of size-limiting rootstocks. Vineyard management strategies to restrict the extent and duration of vegetative growth include root pruning (Dry and Loveys 1998, Giese and Wolf 2009, McArtney and Ferree 1999), aggressive use 
of cover crops (Ingels et al. 2005, Tesic et al. 2007, Wheeler et al. 2005) and various strategies for withholding irrigation water. Irrigation strategies such as regulated deficit irrigation (RDI) can be effectively used to purposefully restrict vegetative growth (Matthews et al. 1987).

Interrow cover crops are routinely used in eastern U.S. vineyards for erosion control, organic matter addition, and improved soil structure. Cool season, perennial, C3 grasses such as Festuca species are favored because of their durability under machinery traffic, their compatibility with most grapevine disease management programs, and their dormancy during hot, dry periods of the summer. Cover crops can also be used to regulate vine vigor by providing an intentional competition with vines for water and other soil resources (Ingels et al. 2005). Shoot growth of grapevines is highly sensitive to water deficits (Matthews et al. 1987), and cover crops offer a potential means of intentionally modifying both the duration and the amount of shoot growth. Competition by cover crops with vines allowed for successful application of RDI strategies in humid New Zealand vineyards (Caspari et al. 1997). While cover crops can be used advantageously to regulate vine size in some situations, they can also cause an undesirable reduction in vine capacity (Celette et al. 2005, Tesic et al. 2007); therefore, cover-crop effects must be carefully monitored to avoid excessive competition with vines. Depending on species, peak water use of the cover crop(s) may differ from peak water use by vines; in a Mediterranean vineyard, a fescue-ryegrass mixed cover crop maximized its water use earlier in the growing season than did the grapevines (Celette et al. 2008).

Rootstocks vary in the extent to which they confer vigor to the scion (Pongracz 1983) and provide an additional means to affect vine capacity and vigor (Dry and Loveys 1998). Furthermore, root systems can be physically altered by seasonal pruning or by intentional restriction to further decrease scion vigor and vine capacity. Physically restricting the rootzone has been done to reduce the vegetative growth of plants, including apples (Byers et al. 2005), peaches (Boland et al. 2000), and grapevines (Wang et al. 2001).

While each of the above techniques has been researched in humid grape regions with varied success, combinations of these techniques have not been systematically studied. We hypothesized that the combination of under-trellis cover crop, a low vigor-imparting rootstock, and intentional root restriction would restrict growth of a characteristically vigorous variety grown in a humid environment. Here we report that the vegetative development, including canopy characteristics, of Cabernet Sauvignon could be favorably altered in a region that averages more than $600 \mathrm{~mm}$ of growing season (April to October) precipitation. Subsequent communications will discuss the consequences of altered growth on components of crop yield and on fruit and wine quality attributes.

\section{Materials and Methods}

The experiment was conducted with Cabernet Sauvignon ENTAV-INRA clone 337 vines grown at Virginia Tech's Alson H. Smith Jr. Agricultural Research and Extension Cen- ter, near Winchester, VA $\left(39^{\circ} 11^{\prime} \mathrm{N} ; 78^{\circ} 28^{\prime} \mathrm{W}\right)$. The soil was a Frederick-Poplimento sandy loam with an approximate rooting depth of 0.75 to $1.50 \mathrm{~m}$ and 110 to $190 \mathrm{~mm} / \mathrm{m}$ available water over the variable rooting depth (NRCS 1987). Preplant soil analyses $(\mathrm{n}=3)$ revealed $65 \%$ sand, $23 \%$ silt, $12 \%$ clay, and $1.8 \%$ organic matter in the top $20 \mathrm{~cm}$, and $63 \%$ sand, $17 \%$ silt, $20 \%$ clay, and $0.8 \%$ organic matter in the 21 to $40 \mathrm{~cm}$ depth. Dolomitic lime was applied (2.0 t/ha) in the year before vineyard establishment. Hourly air temperatures and daily rainfall were recorded with an automated meteorological station located $\sim 300 \mathrm{~m}$ from the vineyard. Heat unit accumulation during the April through October period was calculated by summing the daily mean temperature departure above $10^{\circ} \mathrm{C}$. The vines were planted in May 2006 in rows running generally northeast/southwest at a $3.0 \mathrm{~m}$ (row) x $1.5 \mathrm{~m}$ (vine) spacing. Vines were trained to bilateral cordons $80 \mathrm{~cm}$ aboveground, and shoots were vertically positioned upright with the aid of catch wires.

Three factors were evaluated in a strip-split-split plot design. Main plots compared under-trellis cover crop (UTCC) with conventional floor management; subplots were a rootstock comparison; and sub-subplots evaluated the effects of root restriction. Under-trellis cover crop was a $85 \mathrm{~cm}$ wide strip of creeping red fescue (Festuca rubra) established in fall 2007 combined with a permanent, mixed sward of tall fescue (F. arundinacea) and orchard grass (Dactylis glomerata) in the vineyard interrows. The interrow sward had been established in 2001, well before the establishment of the vineyard. The interrow floor was mowed two to three times per season mainly to benefit foot traffic. The UTCC was not mowed or otherwise managed; however, an area of $\sim 10 \mathrm{~cm}$ radius around the vine trunks was kept free of vegetation with a single spring application of glyphosate and flumioxazin herbicides at label rates. The UTCC treatment was compared with a conventional mid-Atlantic floor management scheme comprising the same interrow groundcover combined with an $85 \mathrm{~cm}$ wide weed-free strip under the trellis. The under-trellis, weed-free strip was maintained with a combination of glyphosate and flumioxazin herbicides applied once around budbreak, with repeat applications of glufosinate-ammonium herbicide as needed to maintain a weed-free strip. Subplots compared rootstocks Riparia Gloire (Riparia) (Vitis riparia), 420A ( $V$. berlandieri $\mathrm{x}$ V. riparia), and 101-14 (V. riparia $\mathrm{x}$ V. rupestris). The sub-subplots compared root manipulation (RM), in which vines were either grown in root-restrictive bags (RR) or were planted with no root restriction (NRR). The root-restriction bags (model RCB-12; High Caliper Products, Oklahoma City, OK) were a UV-stabilized, synthetic fabric cylinder with an open top and a sewn, solid bottom. The fine-mesh fabric allows some moisture movement but restricts root penetration; the volume was $0.015 \mathrm{~m}^{3}$ with a $0.24 \mathrm{~m}$ diam and a $0.32 \mathrm{~m}$ height. The bags were installed at vineyard establishment by inserting the bag into an augured hole and filling the bag, with vine inserted to proper depth, with the augured soil, allowing 3 to $4 \mathrm{~cm}$ of the bag rim to remain above the soil line.

Experimental units were 5-vine plots, and all plots were replicated six times in a strip-split-split plot design where 
each replication (block) included both floor-management practices (strips), each of which compared three rootstocks, spanning three rows (subplots), with each rootstock evaluated with or without root restriction (sub-subplots). Blocks and strips were separated by 5-vine border plots within the row and by buffer rows between the adjacent rows of each block.

General vine management. Vines were dormant-pruned each winter and shoot density was adjusted to 12 shoots per meter of cordon shortly after budbreak. Pest management was typical for the region and was effective. Calcium nitrate was applied once by hand in 2008, prebloom, at a rate of $11.2 \mathrm{~kg} /$ ha N. Calcium nitrate application was repeated in 2009 at a rate of $22.4 \mathrm{~kg} / \mathrm{ha} \mathrm{N}$, split between two equal applications, the first two weeks before bloom and the second two weeks postbloom. Application in 2010 was identical to that in 2008. In all cases, the fertigation-grade calcium nitrate was dissolved in warm water and a volume $(250 \mathrm{~mL})$ appropriate for the intended rate was applied in a ring $\sim 10 \mathrm{~cm}$ from the base of each vine and within the root bags of root-restricted vines.

Crop levels were adjusted each season to avoid overcropping the smaller vines. The RR vines were cluster-thinned at pea berry stage in 2008 to 10 clusters per vine, while NRR vines were adjusted to 20 clusters per vine. Similarly, crop was thinned to $\sim 17$ (RR) or 24 (NRR) clusters per vine in 2009 and to 24 (RR) or 26 (NRR) clusters per vine in 2010, again at approximately pea berry size. Crop yield components and fruit chemistry data were collected each season at harvest, and small-lot wines were made during 2009 and 2010 (unpublished data). Crop per vine and crop load data are presented here to aid interpretation of vegetative response to treatments.

Drip irrigation $(2.27 \mathrm{~L} / \mathrm{hr}$ emitters on $0.3 \mathrm{~m}$ centers) was used intermittently in 2008 , with the midday stem water potential $\left(\Psi_{\text {stem }}\right)$ of the RR vines serving as an indication of need for supplemental water. Methology for $\Psi_{\text {stem }}$ is explained below. The irrigation system was retrofitted in early 2009 so that the RR plots could be independently irrigated of all other plots. As in 2008, irrigation was used as necessary in 2009 and 2010 with the goal of avoiding a $\Psi_{\text {stem }}$ greater than $-1.0 \mathrm{MPa}$.

Vegetative growth measures. Shoot growth rates were obtained by repeated measures of shoot length. Ten representative shoots per plot ( 2 shoots/vine), each bearing at least one inflorescence, were measured on a biweekly basis starting shortly after budbreak and continuing until shoot hedging was needed in the more vigorous plots. Measurements were made from the base of shoot to the shoot apex with a flexible measuring tape. Trunk circumferences were measured at bloom with flexible tape. Vines were double-trunked, therefore both trunks were measured at the third node above the graft union and the two measures summed. Cane pruning weights per vine were collected each winter.

Canopy transects or canopy point quadrat (PQA) analyses were made each year at veraison. The general approach was similar to that outlined in Smart and Robinson (1991) adding the enhanced point quadrat analysis (EPQA) functions of Meyers and Vanden Heuvel (2008). Twenty canopy insertions were made per treatment replicate using a probe insert frame. Probe insertions were made at $20 \mathrm{~cm}$ intervals in the canopy fruit zone. Vines with UTCC were not evaluated in 2008.

To characterize the fruit-zone radiation environment, photosynthetic photon flux measurements were made with a ceptometer (AccuPAR model 80; Decagon Devices, Pullman, WA) \pm 2 hours of solar noon on cloudless days at veraison. The light measurements included a measure of incident radiation with the ceptometer held in the row middle and with the sensor unobstructed and oriented vertically upright (ambient). A second reading was then taken in the canopy fruit zone, where the ceptometer was inserted parallel to and 15 $\mathrm{cm}$ above the cordon, with an average of three readings per canopy insertion: one with the sensor face angled $45^{\circ}$ to the east, a second vertically upright, and the third angled $45^{\circ}$ to the west. Two such readings were taken per treatment replicate and the paired measurements (ambient and fruit zone) provided a means of estimating the light attenuation by the canopy (Meyers and Vanden Heuvel 2008).

Lateral shoot development was rated at the onset of veraison each year. Fully unfolded lateral leaves were counted at nodes three through seven from the base of two primary shoots of the center vine of each 5-vine plot in 2008 and 2009. These leaf counts were then summed to show the number of leaves on these five nodes. A lateral with 10 or more unfolded leaves was given a value of 10 in 2008 and 2009. Lateral shoot assessment was slightly modified in 2010: Fully unfolded leaves were again counted and summed on lateral shoots of nodes three to seven on two shoots per vine, using all five vines per replicate, with no limit on leaf counts above 10 leaves per lateral shoot. Selected shoots were those previously selected and tagged for shoot growth measurements. In addition, for each of the two assessment shoots per vine, the primary shoot (if not hedged) or lateral shoot tips (otherwise) were assigned a binary rating for their degree of shoot-tip activity at veraison. If shoot tips generally appeared to have ceased elongating, or had aborted apices, the shoot was scored "0." If any lateral shoot or the primary shoot tip appeared to be actively elongating, the shoot was scored "1." Shoot-tip activity was then expressed as a decimal value between 0 and 1 when averaged for 60 shoots per treatment.

Leaf gas exchange. Transpiration (E), photosynthesis (A), stomatal conductance $\left(\mathrm{g}_{\mathrm{s}}\right)$, and intercellular $\left[\mathrm{CO}_{2}\right](\mathrm{Ci})$ were periodically measured with a CIRAS-1 (PP Systems, Cambridge, UK) portable, closed system, infrared gas analyzer, fitted with an environmental cuvette. The leaves selected for gas exchange measurements were primary, mature leaves, well exposed to sunlight, and generally in the range of shoot nodes 5 to 10 . Gas exchange measures were made between 1100 and $1630 \mathrm{hr}$, with readings taken 1 min after clasping the leaf with the cuvette. Readings were taken by block $(\sim 45$ min/block) so that changes in gas exchange parameters that occurred during the course of a given day would not bias a particular treatment. Gas exchange conditions were: ambient temperature of 25 to $35^{\circ} \mathrm{C}$, under clear or hazy light conditions; the cuvette light source (LED lamps) provided a photosynthetic photon flux density of $\sim 1300 \mu \mathrm{mols} \cdot \mathrm{m}^{-2} \cdot \mathrm{s}^{-1}$. The 
CIRAS-1 operating conditions were a $\mathrm{CO}_{2}$ reference supply of 385 to $400 \mathrm{ppm}$ and internal pump rate of $200 \mathrm{~mL} / \mathrm{min}$. Relative humidity and $\mathrm{CO}_{2}$ analysis were calibrated monthly per manufacturer's instructions.

Midday leaf and stem (xylem) water potential. Midday leaf water potential $\left(\psi_{\text {leaf }}\right)$ and stem water potential $\left(\psi_{\text {stem }}\right)$ measurements were obtained between 1100 and $1500 \mathrm{hr}$ using a pressure chamber (model 670; PMS Instrument, Albany, OR). Plastic bags covered with aluminum foil were placed on well-exposed, midshoot leaves one hour before the onset of $\psi_{\text {stem }}$ measurements. The time from cutting leaf petioles to insertion and chamber pressurization was typically less than $15 \mathrm{sec}$. The chamber was pressurized with nitrogen gas at a rate of 2 to $4 \mathrm{sec} / 0.1 \mathrm{MPa}$.

Soil moisture measurements. A frequency domain reflectometry soil moisture probe (PR-2, Delta-T Devices, Cambridge, UK) was used to measure volumetric soil water at six depths: 100, 200, 300, 400, 600, and $1000 \mathrm{~mm}$. Sampling was performed biweekly using access tubes that had been installed in a subset of treatments in 2006. Soil moisture probe access tubes were installed under the trellis in each of the UTCC and herbicide main plots with the 420A rootstock subplots and the NRR sub-subplots of each block, for a total of 12 locations. This arrangement allowed only a comparison of UTCC and herbicide main plots, with six replicates each. Individual readings comprised an average of three measures at each soil depth, with the PR-2 probe rotated $120^{\circ}$ between each measure.

Plant tissue analysis. Leaf petioles were collected at cluster closure in 2008 and at bloom in 2009 and 2010 to evaluate treatment impact on plant nutrient status. Petioles were collected from leaves opposite an inflorescence or fruit cluster. Sampling in 2008 was limited to a single sample (50 petioles) collected from each NRR and RR plot. More extensive sampling was done in 2009 and 2010, wherein all treatment combinations were sampled (50 petioles/sample) in triplicate by condensing the six field blocks into three twoblock samples. Petiole samples were oven-dried $\left(60^{\circ} \mathrm{C}\right)$ and analyzed for essential mineral elements by the Pennsylvania State University's Agricultural Analytical Services Laboratory (University Park, PA).

Carbon isotope discrimination. Carbon isotope discrimination, or the tissue ratio of ${ }^{13} \mathrm{C}$ to ${ }^{12} \mathrm{C}$, relative to a standard $\left(\delta^{13} \mathrm{C}\right)$, was determined in leaf tissue and berry samples during the 2009 season. For leaf samples, $0.50 \mathrm{~cm}$ leaf disks $(\mathrm{n}=150 /$ sample) were punched from midshoot leaf laminae on 29 Sept (approximately one month before crop harvest) and oven-dried $\left(60^{\circ} \mathrm{C}\right)$ prior to carbon analysis. Leaf tissue samples were collected from rootstock $420 \mathrm{~A}$ plots, with (RR) or without (NRR) root manipulation (RM), and grown with or without UTCC. Samples were collected from each of the six field replicates of each treatment combination. Triplicate berry samples $(n=50 /$ sample) were collected from the same treatments at harvest $(10$ Oct) and pressed in a hand press. The juice was centrifuged at $3500 \mathrm{rpm}$ for $5 \mathrm{~min}$ to settle solids and was then lyophilized. Stable carbon isotope analyses were performed at the isotope analysis lab of Augustana
College in Sioux Falls, South Dakota, using procedures comparable to those of Jensen et al. (2002) with the exception that the standard for sample comparison was Vienna Pee Dee belemnite.

Statistical data analysis. Analysis of variance (ANOVA) used SAS PROC MIXED analysis (SAS Institute; Cary, NC). A strip-split-split plot design was used to analyze the significance of treatment main effects and their interactions. The fixed effects in this model were under-trellis ground cover [UTGC (under-trellis cover crop vs. herbicide strip)], rootstock, and root manipulation (RM), and their interactions; the random effects were block and block interactions with main effects. ANOVA of tissue mineral analysis data used SAS PROC GLM procedures. Mean separation of rootstock effects was achieved with SAS's least squares means separation with Tukey's adjustment for multiple, pairwise comparisons.

\section{Results}

Precipitation measured April through October was greater than the period average $(636 \mathrm{~mm})$ for $2008(731 \mathrm{~mm})$ and $2009(721 \mathrm{~mm})$, but much less $(352 \mathrm{~mm})$ than average in 2010 . The distribution of rainfall was similar in 2008 and 2009 with more frequent and abundant precipitation prior to veraison and reduced incidence between veraison and harvest (Figure 1). There were few rain events greater than $30 \mathrm{~mm}$ during 2010 and none exceeded $40 \mathrm{~mm}$ prior to harvest that season. April through October heat accumulation (base of $10^{\circ} \mathrm{C}$ ) was 1742 in 2008, 1757 in 2009, and 2174 in 2010. The 2008 and 2009 seasons were cooler than the long-term average (1981) for Winchester, whereas 2010 was much warmer, as was also apparent with the daily temperature profiles (Figure 1).

Root restriction (RR) reduced both the rate and the duration of shoot growth in 2008 with all rootstocks; RR significantly slowed shoot growth from the first through the fourth periods of measure, ending mid-July (Figure 2). Shoots of vines grafted to Riparia grew more slowly than those of vines grafted to either 101-14 or 420A. Rootstock effects were also evident through mid-July. There was a significant rootstock by root manipulation (RM) interaction only for the measurement on 30 June. This interaction appeared to relate to a continued significant rootstock effect (Riparia vs. 101-14 or 420A) for NRR vines, but not for RR vines, which had essentially ceased growth by 30 June (Figure 2). Evaluation of individual shoot growth means also revealed that Riparia shoots exhibited a more pronounced reduction in growth due to RR, compared with the other two rootstocks, at the 30 June measurement. The rootstock effect was not significant in 2009, but vines grafted to 101-14 exhibited the most rapid shoot growth through bloom in 2010 (Table 1). Under-trellis cover crop (UTCC) also depressed shoot growth rate, relative to herbicide plots, although data were only collected on this main effect in 2009 and 2010. As with 2008, RR dramatically reduced shoot growth rate in both 2009 and 2010.

Trunk circumferences of vines grown with UTCC were significantly ( $p \leq 0.0004)$ smaller (11\%) at bloom, 2009, than those of vines grown on herbicide strips. Rootstock also affected trunk circumferences. Combined trunk circumferences 

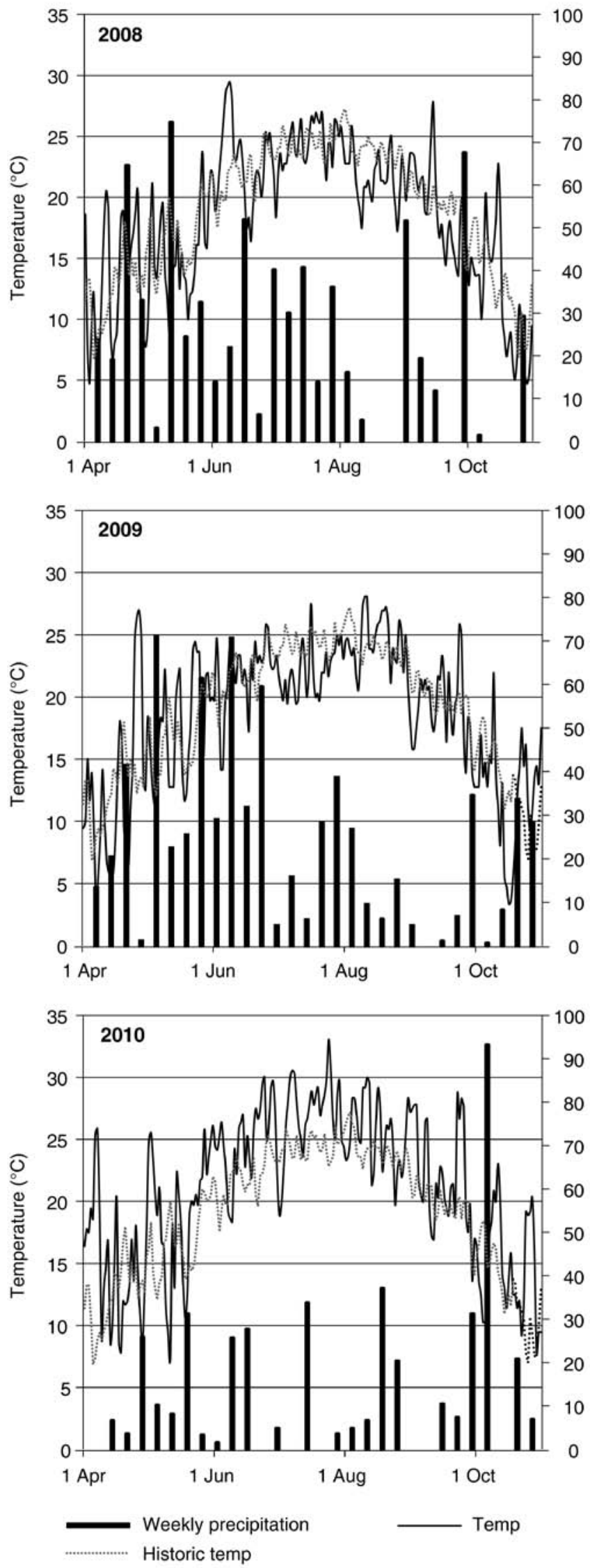

Figure 1 Average daily temperature, historic (1971-2000) average temperature, and precipitation during April-October periods of 2008, 2009, and 2010 for AHS Jr. Agricultural Research and Extension Center, Winchester, Virginia. of vines grafted to Riparia, for example, were significantly $(p \leq 0.0021)$ less $(10.6 \mathrm{~cm})$ than those grafted to 101-14 (12.2 $\mathrm{cm})$ or to $420 \mathrm{~A}(12.1 \mathrm{~cm})$ rootstocks by spring 2009 . Root manipulation also affected trunk circumferences: by spring 2009, RR vines (averaged across other main effects) had a summed trunk circumference mean of $10.2 \mathrm{~cm}$, while NRR vines averaged $13.0 \mathrm{~cm}$, significantly $(p \leq 0.0001)$ greater.

Canopy architecture was affected by UTCC and by RM, but minimally by rootstock. Under-trellis cover crop reduced the occlusion layer number (OLN), the cluster exposure layer (CEL), and the leaf exposure layer (LEL), while simultaneously increasing the cluster (CEFA) and leaf exposure flux availability (LEFA) values, relative to under-trellis herbicide strip plots (Table 2). Like UTCC, RR had uniform, positive effects on decreasing canopy density. Trends were consistent over the three years of measure: either UTCC or RR resulted in a more light-porous fruit zone that ultimately resulted in greater fruit exposure (CEFA) compared with the conventional NRR and herbicide strip floor management. In this

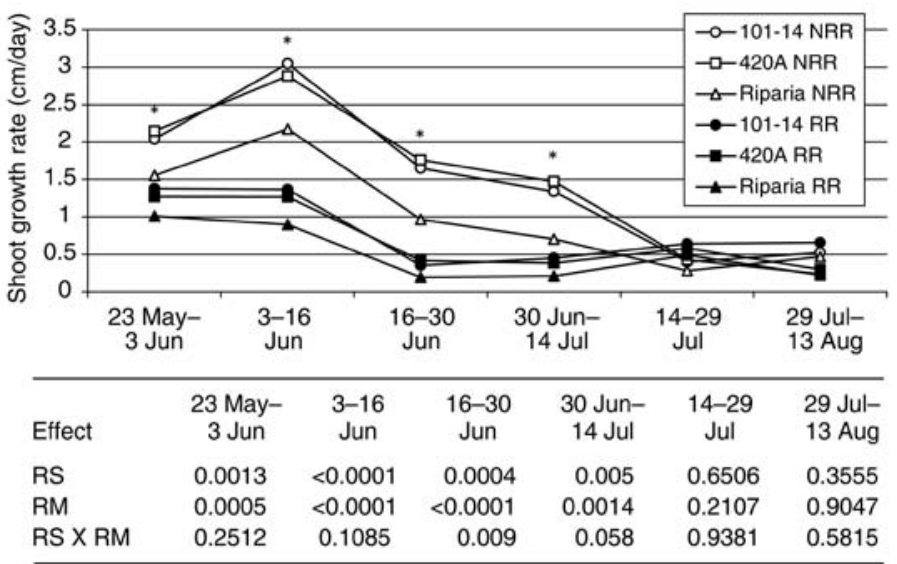

Figure 2 Shoot growth rates as a function of rootstock (RS) and root manipulation (RM) consisting of root restriction (RR) or non-root restriction (NRR) during 2008. Table provides ANOVA significance $(p>\mathrm{F})$ for main effects and their interaction at each measurement period. Only the vines grown on herbicide main plots were measured for shoot growth rate in 2008. Table 1 Shoot growth rates measured in 2009 and 2010 by
main treatment effects, averaged across other treatments. Bloom (75\%) occurred 10 Jun 2009 and 27 May 2010.

\begin{tabular}{lcc}
\hline & \multicolumn{2}{c}{ Shoot growth rate (cm/day) $)^{\mathrm{b}}$} \\
\cline { 2 - 3 } Treatment $^{\mathrm{a}}$ & $\mathbf{2 2}$ May-19 Jun 2009 & 6 May-2 Jun 2010 \\
\hline Herbicide & $2.5 \mathrm{a}$ & $2.5 \mathrm{a}$ \\
UTCC & $1.7 \mathrm{~b}$ & $2.0 \mathrm{~b}$ \\
101-14 & 2.2 & $2.3 \mathrm{a}$ \\
420A & 2.1 & $2.1 \mathrm{~b}$ \\
Riparia & 2.1 & $2.2 \mathrm{~b}$ \\
NRR & $2.6 \mathrm{a}$ & $2.7 \mathrm{a}$ \\
RR & $1.6 \mathrm{~b}$ & $1.7 \mathrm{~b}$ \\
\hline
\end{tabular}

aUTCC: under-trellis cover crop; NRR: non-root restricted; RR: root restricted.

${ }^{\mathrm{b}}$ Means within treatment groups and columns that are followed by different letters differ at $p \leq 0.0001$. 
regard, main effects of $\mathrm{RR}$ were more effective than main effects of UTCC, and the combined effects were generally additive. While rootstock exerted no significant main effects on the canopy characteristics measured with EPQA, there were several instances of significant rootstock by RM interaction (Table 2); however, the interactions were not consistent from year-to-year and the viticultural implications were of questionable relevance. Similarly, while there were significant interactions between RM and UTGC for two of the responses, a stable pattern of interaction was not apparent.

Canopy cluster symmetry (CCS), with a value that ranges from -1 to 1 , ranged from -0.195 to 0.223 (data not shown). Thus, all canopies were essentially symmetrical from east to west through the fruit zone.

Root restriction and Riparia rootstock produced significant reductions $(p \leq 0.001)$ in lateral shoot development in 2008 (data not shown). Root restriction also caused a significant ( $p$ $\leq 0.0336$ ) reduction in lateral shoot development in 2009. The effects of treatment on lateral shoot development are illustrated with the data collected in 2010 (Figure 3). The sum of lateral leaves at nodes 3 to 7 of vines on herbicide strip plots was reduced by as much as $50 \%$ by RR and by another 20 to $30 \%$ when RR was combined with UTCC. The impact of RR on lateral shoot development was more pronounced for vines grown on herbicide strips than it was for those grown with UTCC. Treatments also affected the duration of shoot growth, as judged by the proportion of active shoot tips at veraison (Figure 3 ). Less than $20 \%$ of RR vines exhibited actively growing shoots at veraison, whereas 30 to $60 \%$ of NRR vines still had active shoot tips at that time. For a given rootstock, UTCC vines were more apt to have ceased shoot elongation by veraison than vines maintained with herbicide strips.

Cane pruning weights of the 2008 and 2009 seasons were depressed both by UTCC and by RR and were affected by rootstock (Figure 4). Riparia rootstock produced lower cane pruning weights than did the other two rootstocks, which did not differ from each other. The additive vine size depressive effects of RR and UTCC resulted in vines that were less than $0.30 \mathrm{~kg} / \mathrm{m}$ of canopy, whereas the NRR vines maintained with herbicide strips produced the greatest cane pruning weights,

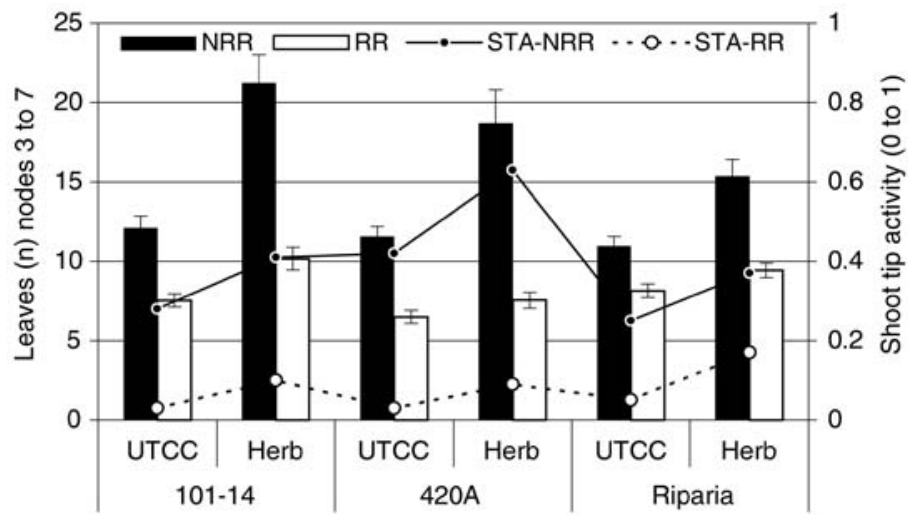

Figure 3 Mean sum ( \pm standard errors) of lateral shoot leaves at nodes 3 to 7 and shoot-tip activity (STA) at veraison 2010 for non-root-restricted (NRR) and root-restricted (RR) vines for each rootstock and UTGC combination.

Table 2 Selected enhanced point quadrat analysis variables and treatment significance collected at or around veraison for under-trellis ground cover, rootstock, and root manipulation during three seasons, 2008-2010.

\begin{tabular}{|c|c|c|c|c|c|c|c|c|c|c|c|c|c|}
\hline \multirow[b]{2}{*}{ Treatment $^{a}$} & \multicolumn{3}{|c|}{$\begin{array}{c}\text { Occlusion layer } \\
\text { number }\end{array}$} & \multicolumn{3}{|c|}{$\begin{array}{c}\text { Cluster exposure } \\
\text { layer }^{\mathrm{b}}\end{array}$} & \multicolumn{3}{|c|}{$\begin{array}{c}\text { Leaf exposure } \\
\text { layerb }^{\mathrm{b}}\end{array}$} & \multicolumn{2}{|c|}{$\begin{array}{l}\text { Cluster exposure } \\
\text { flux availability }\end{array}$} & \multicolumn{2}{|c|}{$\begin{array}{l}\text { Leaf exposure } \\
\text { flux availability }\end{array}$} \\
\hline & 2008 & 2009 & 2010 & 2008 & 2009 & 2010 & 2008 & 2009 & 2010 & 2009 & 2010 & 2009 & 2010 \\
\hline \multicolumn{14}{|l|}{ UTGC } \\
\hline UTCC & & 1.73 & 2.01 & & 0.26 & 0.34 & & 0.16 & 0.14 & 0.5 & 0.43 & 0.5 & 0.52 \\
\hline Herbicide & 1.76 & 2.26 & 2.24 & 0.57 & 0.54 & 0.50 & 0.53 & 0.26 & 0.22 & 0.3 & 0.33 & 0.5 & 0.46 \\
\hline \multicolumn{14}{|l|}{ Rootstock } \\
\hline $101-14$ & 1.73 & 2.06 & 2.19 & 0.77 & 0.49 & 0.41 & 0.51 & 0.18 & 0.20 & 0.3 & 0.38 & 0.5 & 0.47 \\
\hline $420 \mathrm{~A}$ & 1.92 & 1.89 & 2.04 & 0.58 & 0.39 & 0.43 & 0.58 & 0.23 & 0.17 & 0.5 & 0.37 & 0.5 & 0.50 \\
\hline Riparia & 1.63 & 2.04 & 2.14 & 0.37 & 0.31 & 0.42 & 0.50 & 0.21 & 0.18 & 0.4 & 0.38 & 0.5 & 0.49 \\
\hline \multicolumn{14}{|l|}{ RM } \\
\hline NRR & 2.10 & 2.25 & 2.44 & 0.69 & 0.46 & 0.55 & 0.60 & 0.26 & 0.23 & 0.4 & 0.30 & 0.5 & 0.44 \\
\hline $\mathrm{RR}$ & 1.41 & 1.74 & 1.80 & 0.45 & 0.34 & 0.29 & 0.47 & 0.16 & 0.13 & 0.5 & 0.46 & 0.6 & 0.54 \\
\hline \multicolumn{14}{|l|}{ Significance $^{d}$} \\
\hline UTGC & & 0.007 & ns & & 0.017 & 0.012 & & 0.0105 & 0.0001 & 0.017 & 0.010 & 0.0053 & 0.013 \\
\hline RS & ns & ns & ns & ns & $\mathrm{ns}$ & ns & ns & ns & ns & ns & ns & ns & ns \\
\hline RS $x$ UTGC & & ns & ns & & ns & ns & & ns & ns & ns & ns & ns & ns \\
\hline $\mathrm{RM}$ & 0.003 & 0.007 & $<0.0001$ & ns & ns & $<0.0001$ & ns & 0.013 & $<0.0001$ & ns & $<0.0001$ & 0.0038 & 0.002 \\
\hline $\mathrm{RS} \times \mathrm{RM}$ & ns & ns & 0.027 & ns & ns & 0.002 & ns & ns & ns & & 0.026 & & ns \\
\hline RM x UTGC & & 0.005 & ns & & ns & ns & & 0.0328 & ns & ns & ns & ns & ns \\
\hline RM $\times$ RS $\times$ UTGC & & ns & 0.007 & & ns & ns & & ns & ns & ns & ns & ns & ns \\
\hline
\end{tabular}

aUTGC: under-trellis groundcover; UTCC: under-trellis cover crop; RM: root manipulation; NRR: non-root restricted; RR: root restricted; RS: rootstock.

bOnly the herbicide plots were assessed in 2008.

'Canopy sunlight penetration measures were not made in 2008, therefore CEFA and LEFA values were not obtained that season.

dSignificance of treatment effects and interactions $(p>F$; ns $=$ not significant). 
regardless of rootstock. Canopy EPQA parameters measured at veraison in 2009 were regressed on cane pruning weights for that season to evaluate those relationships. The EPQA metric that showed the closest correspondence to pruning weight was the occlusion layer number (OLN), which showed a significant, positive, linear relationship to increasing pruning weight such that pruning weights greater than $0.80 \mathrm{~kg} / \mathrm{m}$ of canopy were consistently associated with OLNs of 2.0 or higher (Figure 5). Although not significant, the percentage of ambient photosynthetically active radiation that was measured within the fruit zone at veraison was inversely related to cane pruning weight, with typically less than $4 \%$ available sunlight measured with those vines that had pruning weights that exceeded $0.60 \mathrm{~kg} / \mathrm{m}$ of canopy (data not shown).
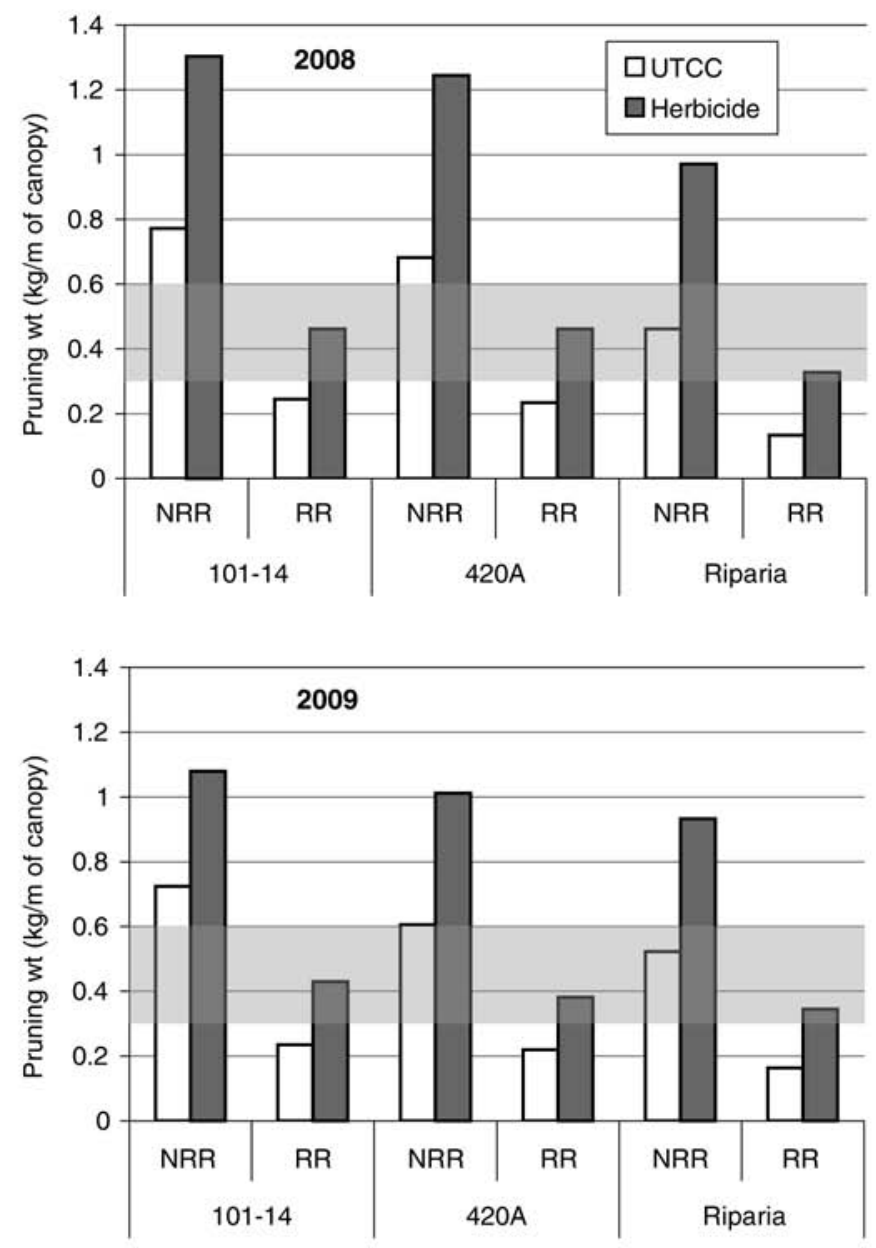

\begin{tabular}{lcc}
\hline Effect & 2008 & 2009 \\
\hline UTGC & $<0.0001$ & $<0.0001$ \\
RS & 0.0064 & 0.035 \\
RS $\times$ UTGC & $n s$ & $n s$ \\
RM & $<0.0001$ & $<0.0001$ \\
RM $\times$ UTGC & $<0.0001$ & $<0.0001$ \\
RM $\times$ RS $\times$ UTGC & 0.0009 & $n s$ \\
\hline
\end{tabular}

Figure 4 Cane pruning weights by treatment combination, 2008 and 2009. Shaded bands represent optimum pruning weight values suggested by Smart and Robinson (1991). Table provides ANOVA significance $(p>F)$ for main effects and their interactions for each year.
Crop yield per vine was deliberately increased over the 2008 to 2010 period as vines matured and was therefore a product of both the crop adjustments and the response to treatment (Table 3). Under-trellis cover crop and RM were associated with lower crop per vine in all three seasons, while rootstock affected yield only in 2008 and 2009. The rootstock effect was due to Riparia, which differed from the other two rootstocks with respect to greater berries per cluster and greater berry weight, but not different cluster count per vine (unpublished data). Yield differences between RR and NRR vines were, on average, reduced from $186 \%$ in 2008 to only $23 \%$ in 2010 with the herbicide plots, and from $236 \%$ to $35 \%$ in the UTCC plots over the same period (Table 3). The initial root manipulation differences in crop (e.g., $186 \%$ vs. $236 \%$ in 2008) between UTCC and herbicide plots appeared to generate the significant RM x UTGC crop yield interactions in 2008 and 2009. Crop loads ranged from 2.0 in 2008 to a high of $\sim 7.1$ in 2010. Crop loads were affected by all three main effects, but were most notably increased by RR. Riparia rootstock consistently produced the greatest crop loads and 101-14 the least, which inversely matched the pruning weight divisors used to generate crop load (Figure 4).

Leaf gas exchange varied only slightly between UTCC and herbicide plots as measured in 2009 (Figure 6). Net assimilation (A) was slightly elevated for herbicide plots through mid-July, but was comparable to UTCC plots for the last two measures of that season. Transpiration (E), stomatal conductance $\left(\mathrm{g}_{\mathrm{s}}\right)$, and intercellular $\mathrm{CO}_{2}$ concentration $\left(\mathrm{C}_{\mathrm{i}}\right)$ were all very similar between cover crop and herbicide treatments for the entire season (Figure 6). By contrast, A, E, $g_{s}$, and $C_{i}$ were all lower for RR vines than for NRR vines (Figure 7) during the period from mid-July through mid-September 2009.

Leaf water potential values in 2008 showed that $\psi_{\text {MD leaf }}$ values were generally greater (more negative) for RR vines than for NRR vines until mid-September when more frequent irrigation of RR vines negated the treatment effects without stimulating renewed shoot growth (data not shown). Measures of vine water potential focused on stem water potential $\left(\psi_{\text {stem }}\right)$ in 2009 and 2010, with 2009 data representative of those

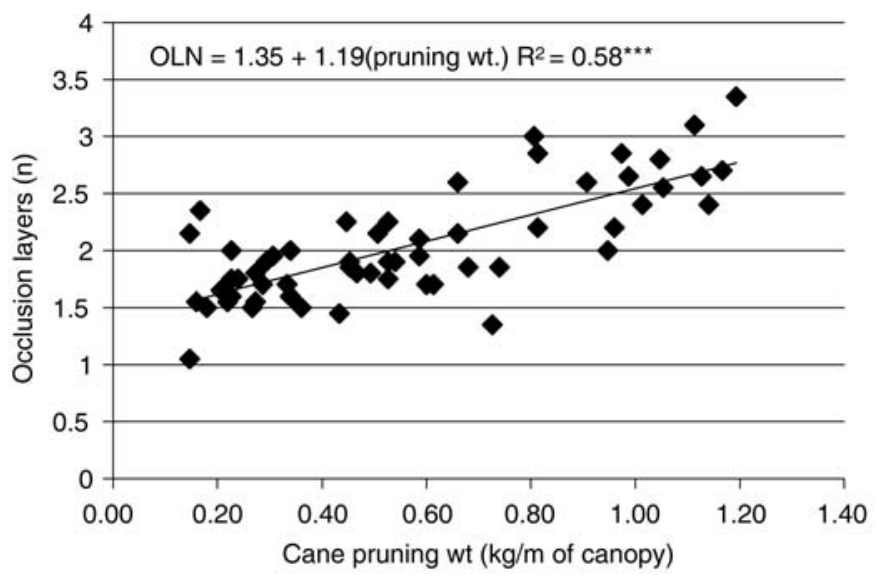

Figure 5 Occlusion layer number (OLN) assessed at veraison, 2009, regressed on cane pruning weights of 2009 growing season, across all treatments $(n=60)$. 
measures. Root restriction resulted in significantly greater (more negative) $\psi_{\text {stem }}$ values than measured with the NRR vines during the 2009 season (Figure 8). Midday $\psi_{\text {stem }}$ values had dropped to $-0.8 \mathrm{MPa}$ by early July, and possibly earlier, as significant treatment effects were apparent as early as the 10 June assessment (full bloom). Averaged across other main effects, UTCC vines had lower $\psi_{\text {stem }}$ values after mid-July 2009 than did vines grown with herbicide below the trellis (Figure 8). Subtle, but nonsignificant differences in $\psi_{\text {stem }}$ were observed between rootstocks in 2009 (Figure 8). There was a significant $(p=0.054)$ interaction between groundcover and RM on 10 June. The difference in $\psi_{\text {stem }}$ between NRR and RR vines grown with UTCC was less (0.09 MPa lower for RR vines) than the $\psi_{\text {stem }}$ difference (0.14 MPa lower for RR vines) when vines were grown on herbicide strips. In other words, the use of herbicide strips amplified the differences in $\psi_{\text {stem }}$ observed with RR, but only on 10 June; this particular interaction did not reoccur on subsequent dates of measure in 2009. There were significant interactions between rootstock and RM at each of the last three dates of $\psi_{\text {stem }}$ measured in 2009. For example, a significant $(p=0.0037)$ interaction on 21 July showed that $420 \mathrm{~A}$ produced the greatest depression in $\psi_{\text {stem }}(0.35 \mathrm{MPa})$ between NRR and RR treatments, compared to differences of $0.23 \mathrm{MPa}$ for 101-14 and 0.16 MPa for Riparia between the RM treatments. The relative ranking of rootstock effects varied, however, with subsequent measures; 101-14 showed the greatest spread on 12 Aug and Riparia showed the greatest spread on $18 \mathrm{Sept}$ (data not shown).

Herbicide plots tended to have slightly lower soil moisture levels compared to UTCC plots at the 100 and $400 \mathrm{~mm}$ depths, whereas that pattern was reversed at the $200 \mathrm{~mm}$ depth (data not shown). Excepting the $600 \mathrm{~mm}$ level, differences in soil moisture content due to floor management were significantly different at relatively few points in time, and at no time were differences noted at $1000 \mathrm{~mm}$ depth. Soil moisture content was, however, consistently affected by groundcover at the $600 \mathrm{~mm}$ depth (Figure 9). The UTCC plots typically had lower soil moisture at $600 \mathrm{~mm}$, often significantly so, than did herbicide plots, over the three seasons of evaluation. A follow-up soil moisture reading obtained $1 \mathrm{Apr}$ 2011, before active cover-crop development, was consistent with data from previous years, with $46 \%$ (herbicide) and $41 \%$ (UTCC) volumetric soil mositure at the $600 \mathrm{~mm}$ depth, no difference at $1000 \mathrm{~mm}$, and generally higher ( $8 \%$ on average) soil mositure content with UTCC plots at each of the 100 to $400 \mathrm{~mm}$ depths.

Plant tissue analyses conducted at bloom in 2008 allowed only a casual comparison of root manipulation and suggested suboptimal nitrogen and phosphorus levels in vines of both RM treatments, with potassium and magnesium at or above sufficiency levels (Table 4). Nitrogen and phosphorus values both increased in 2009, with no treatment effects observed with N; however, vines with RR had a $60 \%$ lower phosphorous concentration in petioles than vines with NRR. Vineyard floor management did not significantly affect nutrient levels in 2009, although P levels of UTCC vines were substantially lower than those of vines grown with herbicide plots. Vines grafted to $420 \mathrm{~A}$ had a $38 \%$ and $40 \%$ lower petiole potassium concentration compared to vines grafted to 101-14 and Riparia, respectively. Plant tissue analysis results of 2010 were

Table 3 Average crop yield per vine and crop load as affected by under-trellis ground cover, rootstock, and root manipulation over three seasons, 2008-2010.

\begin{tabular}{|c|c|c|c|c|c|c|c|}
\hline \multirow[b]{2}{*}{ UTGC/RSa } & \multirow[b]{2}{*}{$\mathbf{R M}^{\mathrm{a}}$} & \multicolumn{3}{|c|}{ Vine yield (kg) } & \multicolumn{3}{|c|}{ Crop load } \\
\hline & & 2008 & 2009 & 2010 & 2008 & 2009 & 2010 \\
\hline \multicolumn{8}{|l|}{ UTCC } \\
\hline \multirow[t]{2}{*}{ 101-14 } & NRR & 1.9 & 1.9 & 3.1 & 1.6 & 1.8 & 2.8 \\
\hline & $\mathrm{RR}$ & 0.7 & 1.3 & 2.4 & 1.9 & 3.6 & 5.8 \\
\hline \multirow[t]{2}{*}{$420 \mathrm{~A}$} & NRR & 2.5 & 2.0 & 3.3 & 2.4 & 2.3 & 3.2 \\
\hline & $\mathrm{RR}$ & 0.8 & 1.6 & 2.7 & 2.4 & 5.2 & 7.1 \\
\hline \multirow[t]{2}{*}{ Riparia } & NRR & 3.0 & 2.7 & 3.7 & 4.3 & 3.2 & 3.7 \\
\hline & $\mathrm{RR}$ & 0.7 & 1.6 & 2.4 & 3.6 & 5.9 & 6.7 \\
\hline \multicolumn{8}{|l|}{ Herbicide } \\
\hline \multirow[t]{2}{*}{$101-14$} & NRR & 3.5 & 3.3 & 3.8 & 1.7 & 2.0 & 2.4 \\
\hline & $\mathrm{RR}$ & 1.3 & 2.0 & 3.1 & 1.9 & 3.3 & 4.6 \\
\hline \multirow[t]{2}{*}{$420 \mathrm{~A}$} & NRR & 4.1 & 3.2 & 3.7 & 2.1 & 2.2 & 2.6 \\
\hline & $\mathrm{RR}$ & 1.6 & 2.1 & 2.9 & 2.3 & 3.9 & 5.8 \\
\hline \multirow[t]{2}{*}{ Riparia } & NRR & 5.0 & 4.2 & 4.1 & 3.4 & 3.0 & 3.0 \\
\hline & $\mathrm{RR}$ & 1.5 & 2.4 & 3.4 & 3.1 & 4.6 & 5.6 \\
\hline \multicolumn{8}{|l|}{ Significance $^{b}$} \\
\hline UTGC & & 0.0006 & $<0.0001$ & 0.0104 & ns & 0.0454 & 0.0057 \\
\hline RS & & 0.0205 & 0.0093 & ns & 0.0002 & 0.0003 & 0.0013 \\
\hline RS $\times$ UTGC & & ns & ns & ns & ns & ns & ns \\
\hline $\mathrm{RM}$ & & $<0.0001$ & 0.0006 & 0.0080 & ns & 0.0008 & 0.0002 \\
\hline RM x UTGC & & $<0.0001$ & $<0.0001$ & ns & 0.0119 & 0.0011 & 0.0168 \\
\hline RM $x$ UTGC $\times$ RS & & $<0.0001$ & $<0.0001$ & ns & 0.0014 & ns & 0.0301 \\
\hline
\end{tabular}

aUTGC: under-trellis groundcover; UTCC: under-trellis cover crop; RM: root manipulation; NRR: non-root restricted; RR: root restricted; RS: rootstock.

${ }^{b}$ Significance of treatment effects and interactions ( $p>F ; \mathrm{ns}=$ not significant). 
similar to those of 2009 , although $\mathrm{N}$ was decreased and $\mathrm{K}$ increased by UTCC, compared to maintenance with herbicide strips (Table 4). Rootstock effects were evident with all of the macronutrients in 2010, and generally paralleled the results observed in 2009. In particular, Riparia depressed N, $\mathrm{P}, \mathrm{K}$, and especially $\mathrm{Mg}$ levels relative to one or both of the other rootstocks. The significant reduction in petiole $\mathrm{K} \mathrm{ob-}$
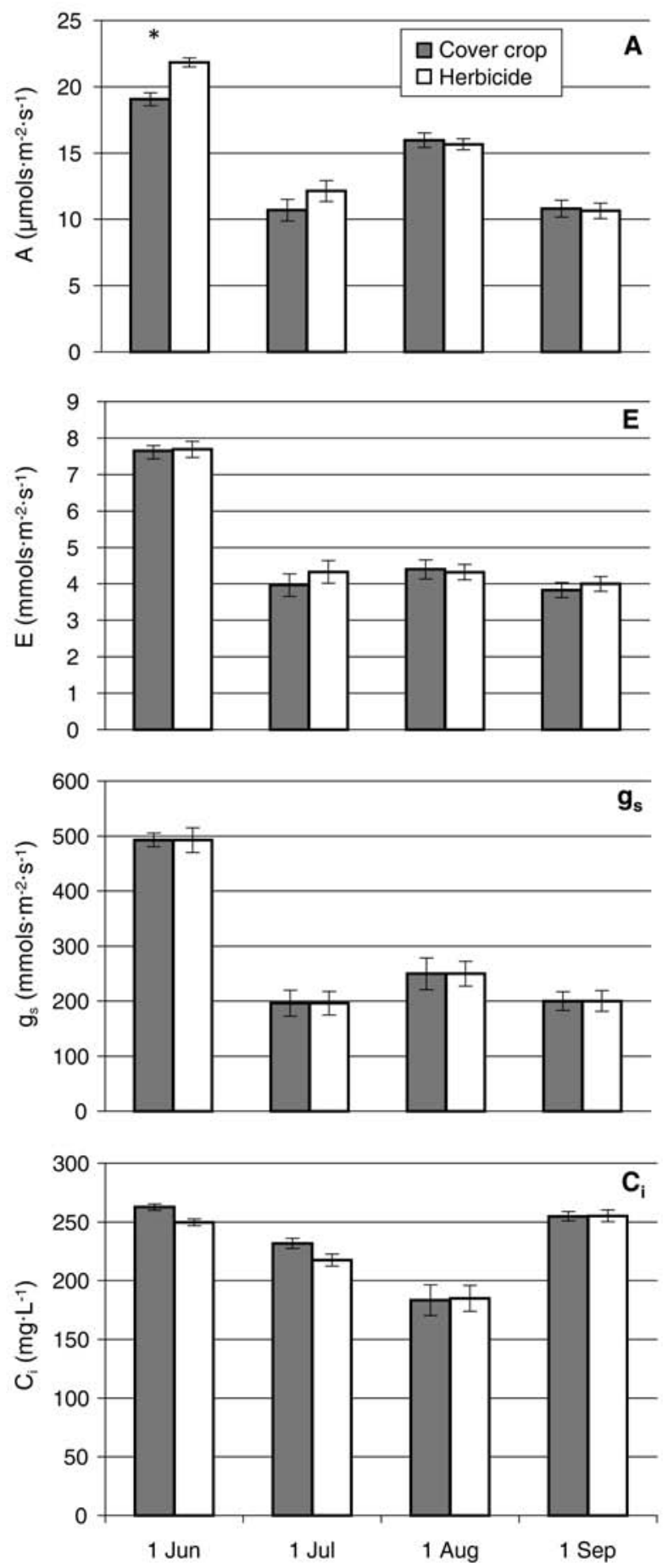

Figure 6 Net assimilation $(\mathbf{A})$, transpiration $(\mathbf{E})$, stomatal conductance $\left(\mathbf{g}_{\mathrm{s}}\right)$, and intercellular $\mathrm{CO}_{2}$ concentration $\left(\mathbf{C}_{\mathbf{i}}\right)$ of vines grown either with undertrellis cover crop or on herbicide strips in 2009. Bloom (50\%) occurred 8 June and onset of veraison (10\%) occurred 27 July. Bars are means ( $n=$ $36) \pm$ standard errors averaged across rootstocks and root manipulation treatments. Asterisk denotes a significant $(p \leq 0.05)$ treatment difference. served with 420A was also consistent in the two years examined. Treatment interactions occurred with some responses including two-way and three-way interactions for $\mathrm{N}$ levels in 2010, and many RM by UTGC interactions (Table 4). Calcium levels (data not shown) were only affected by RM ( $p$ $\leq 0.0001)$ in 2010 : NRR vines had $1.65 \% \mathrm{Ca}$, whereas $\mathrm{RR}$ vines had $1.43 \%$. Sulfur and the trace essential elements were
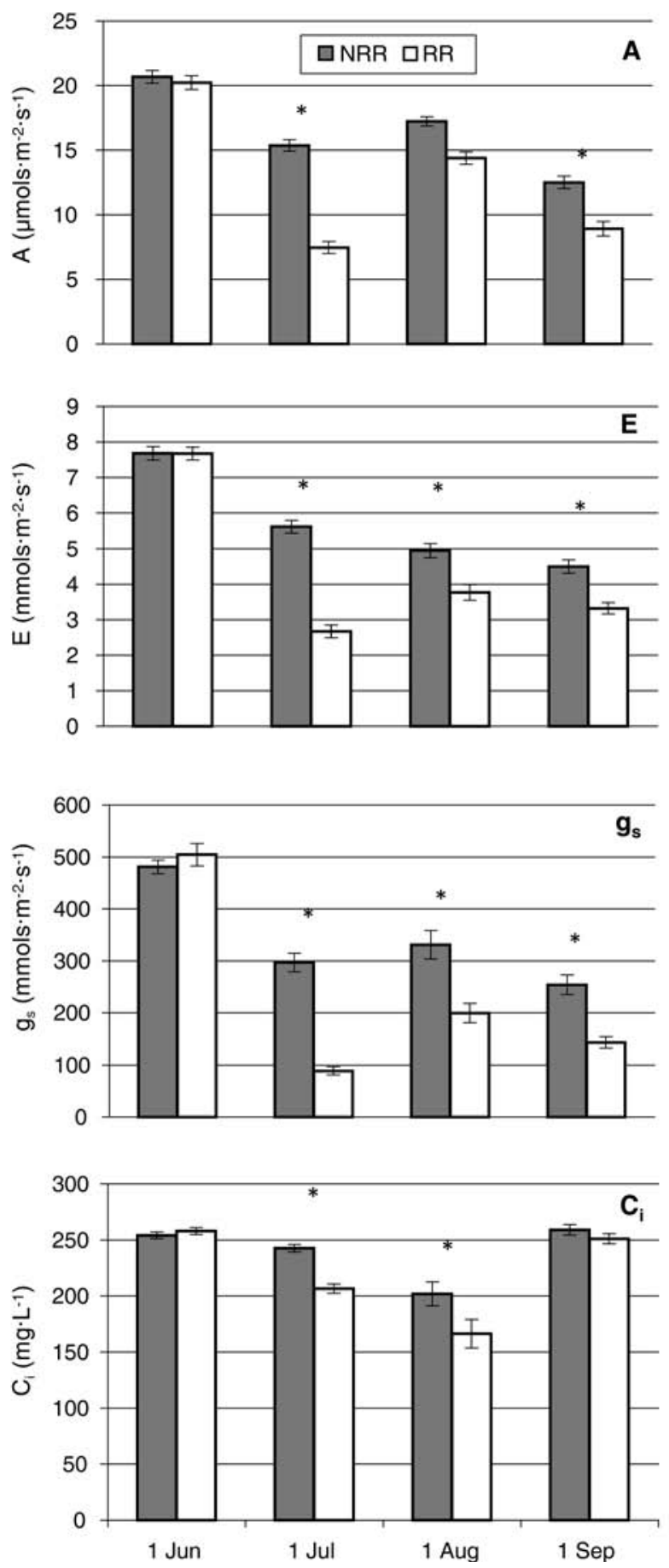

Figure 7 Net assimilation (A), transpiration (E), stomatal conductance $\left(\mathbf{g}_{\mathbf{s}}\right)$, and intercellular $\mathrm{CO}_{2}$ concentration $\left(\mathbf{C}_{\mathrm{i}}\right)$ of vines grown with (RR) or without (NRR) root manipulation in 2009. Bloom (50\%) occurred 8 June while the onset of veraison (10\%) occurred 27 July. Bars are means (n = 36) \pm standard errors averaged across rootstocks and groundcover treatments. Asterisks denote a significant $(p \leq 0.05)$ treatment difference. 
at or above sufficiency level each year, and either minor or no treatment effects on tissue concentration were observed (data not shown).

Leaf disks collected approximately one month before grape harvest in 2009 revealed $\delta^{13} \mathrm{C}$ values that ranged from -26.74 to -29.70 (Table 5). Root manipulation, but not UTCC, affected $\delta^{13} \mathrm{C}$ levels, with RR causing a more positive $\delta^{13} \mathrm{C}$ value. A similar response was observed with juice from berries sampled at harvest; juice $\delta^{13} \mathrm{C}$ values ranged from -23.80 to -27.97, and mean $\delta^{13} \mathrm{C}$ values for NRR and RR vines were -27.71 and -24.21 , respectively, a highly significant $(p \leq 0.001)$ difference. Under-trellis floor management did not cause significant differences in $\delta^{13} \mathrm{C}$, nor were there significant interactions between floor management and root manipulation.

\section{Discussion}

Our aim was to evaluate a range of strategies that could be used to favorably restrict the vegetative development of grapevines in a humid environment. Our long-term goal is
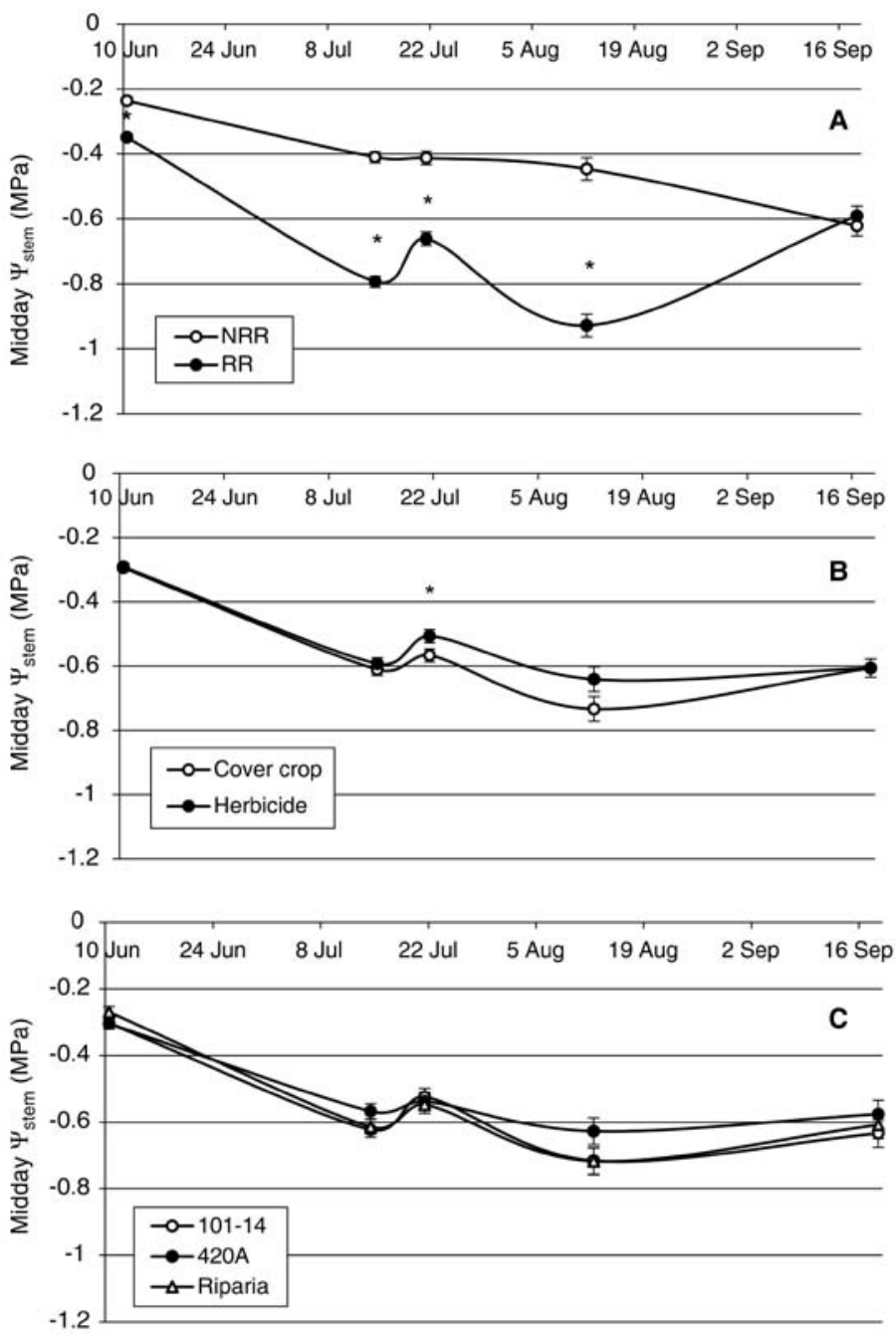

Figure 8 Midday $\psi_{\text {stem }}$ as affected by root restriction (A), groundcover management (B), or rootstock (C) in 2009. Bloom (50\%) occurred 8 June while the onset of veraison (10\%) occurred 27 July. Data are means \pm standard errors. Asterisks denote significant $(p \leq 0.05)$ root restriction or groundcover effects. to better understand how vine capacity and "balance" impact fruit and wine quality attributes. The antecedent to that long-term goal is the establishment of a stable range of vine capacities upon which fruit composition and wine analyses can be performed. Modification of vegetative growth was expected, and generally followed a trend wherein root restriction $>$ UTCC $>$ rootstock effects on vine size, shoot vigor, and associated elements of canopy density. Additive effects were also observed: vines grafted to Riparia and grown in root-restrictive bags in conjunction with an under-trellis cover crop exhibited the greatest reduction in vegetative development.

Root restriction, as used in our experiment, substantially restricted root exploration of soil, limited the vine's uptake of water and nutrients, and was associated with suppression of vegetative growth. Crop was intentionally reduced on these vines to a generally accepted crop load range of 5 to 10 (Smart and Robinson 1991); therefore, we do not believe that crop, per se, was limiting vegetative development of $R R$ vines. Crop loads were, however, lower than optimal on the NRR vines, which might have contributed to the greater
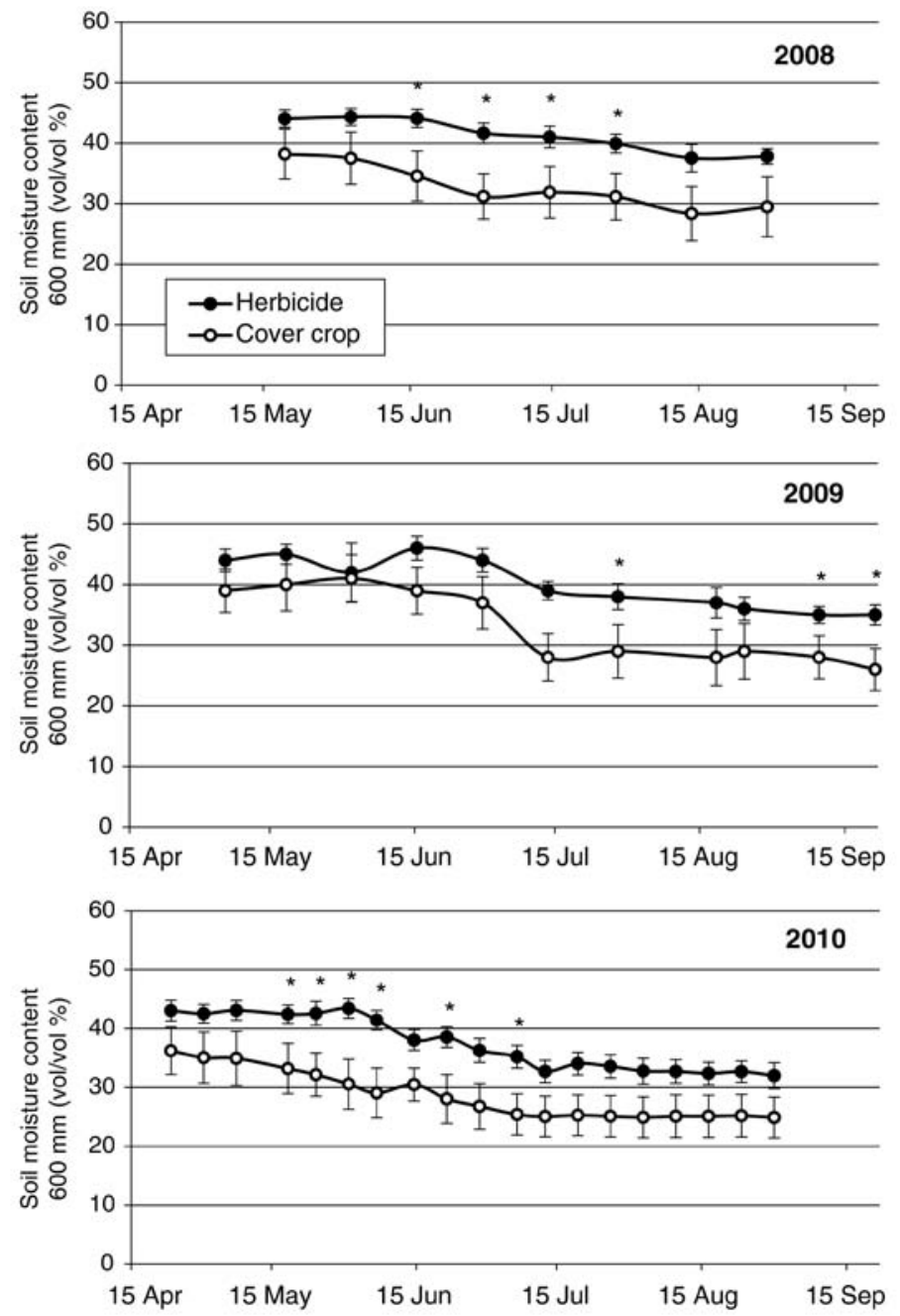

Figure 9 Volumetric soil moisture content at $600 \mathrm{~mm}$ depth for plots with under-trellis cover crop and plots with herbicide strips below the trellis over three seasons, 2008-2010 Asterisks denote significant $(p \leq 0.05)$ groundcover effects. Data are means \pm standard errors of six measures. 
vegetative development measured with those vines. In $V$. vinifera cv. Kyoho grapevines grown in restricted volumes of soil buried in the bulk soil, reduced soil volume treatments reduced grapevine vegetative growth and increased the accumulation of skin color, juice soluble solids, and improved fruit set (Wang et al. 2001). The mechanism suggested for the reduced vegetative growth was a more rapid depletion of soil moisture in the restricted root zone (Wang et al. 2001).

In the current study, RR resulted in reduced midday leaf $\left(\psi_{\text {leaf }}\right)\left(2008\right.$ season) and stem water potentials $\left(\psi_{\text {stem }}\right)$, with both techniques clearly separating RR from NRR treatment. Stem water potential appeared to correlate well with our measured growth and gas exchange responses and has been shown in other studies to be a reliable index of vine water status (Naor and Wample 1994, Williams and Araujo 2002). The RR vines also exhibited reductions in $\mathrm{A}, \mathrm{g}_{\mathrm{s}}, \mathrm{C}_{\mathrm{i}}$, and $\mathrm{E}$, relative to NRR vines (Figure 7), which correlated with reduced water status as measured by midday $\psi_{\text {stem }}$ (Figure 8 ). The magnitude of difference in $\psi_{\text {stem }}$ between RR and NRR vines was similar to that observed with irrigated vs. non-irrigated $V$. labruscana cv. Concord vines (Naor and Wample 1994); however, RR vines did not attain the degree of water stress $\left(\psi_{\text {stem }}<-1.0\right.$ $\mathrm{MPa}$ ) observed with the Concord vines ( -1.4 MPa) in the Naor and Wample study. Finally, the more positive $\delta^{13} \mathrm{C}$ of $R R$ vines, relative to NRR vines, points to a chronic reduction in water status and gas exchange. Therefore, we surmise that water deficit was the primary mechanism by which root restriction suppressed vegetative growth. We do not, however, dismiss the possible, contributing role of reduced nitrogenous and carbohydrate reserves or possible root-to-shoot signaling in response to root restriction. More detailed studies would be required to determine the potential role of those factors.
It is beyond the scope of this paper, but additional investigation with our system could explore point-in-time evaluations of water use efficiency (A/E) and more detailed evaluation of potential, nonstomatal treatment effects on photosynthesis.

At $0.015 \mathrm{~m}^{3}$ volume $(15 \mathrm{~L})$, the root-restrictive bags used here were acutely restrictive. A single RR vine exhumed in Nov 2009 showed that some roots had penetrated the bag fabric and enlarged at the bag interface to as much as $1 \mathrm{~cm}$ diam. These roots were easily broken off at the bag interface, revealing a slender $(<1.0 \mathrm{~mm})$ trace of apparently functional stele transcending the fabric. The major diameter of the swollen root comprised darkened, apparently nonfunctional callus tissue, as has been observed with other plants grown in rootcontainment bags (Byers et al. 2005). Thus, despite the small volume of soil within the root-restrictive bags, the potential exists for RR vines to obtain some moisture and nutrients from the bulk soil. We view the use of root restriction to be an effective research tool to modify vine development and to

Table 5 Carbon isotope discrimination $\left(\delta^{13} \mathrm{C}\right)$ measured in leaf laminae and in juice from berries sampled at general fruit harvest in 2009 with vines grafted to $420 \mathrm{~A}$ rootstock.

\begin{tabular}{lcc}
\hline & \multicolumn{2}{c}{$\boldsymbol{\delta}^{\mathbf{1 3}} \mathbf{C}(\% \circ)$} \\
\cline { 2 - 3 } Treatment $^{\mathrm{a}}$ & Leaf tissue & Berry juice \\
\hline Herbicide + NRR & $-29.07 \mathrm{a}^{\mathrm{b}}$ & $-27.68 \mathrm{a}$ \\
UTCC + NRR & $-29.31 \mathrm{a}$ & $-27.73 \mathrm{a}$ \\
Herbicide + RR & $-27.34 \mathrm{~b}$ & $-24.40 \mathrm{~b}$ \\
UTCC + RR & $-27.38 \mathrm{~b}$ & $-24.03 \mathrm{~b}$
\end{tabular}

aNRR: non-root restricted; UTCC: under-trellis cover crop; RR: root restricted.

bMeans within columns that are followed by the same letter do not differ at $p \leq 0.05$.

Table 4 Leaf petiole concentrations of macronutrients at bloomtime in three seasons as affected by under-trellis ground cover, rootstock, and root manipulation.

\begin{tabular}{|c|c|c|c|c|c|c|c|c|c|c|c|c|}
\hline \multirow[b]{2}{*}{ Treatment $^{\mathrm{a}}$} & \multicolumn{3}{|c|}{ Nitrogen (\%) } & \multicolumn{3}{|c|}{ Phosphorus (\%) } & \multicolumn{3}{|c|}{ Potassium (\%) } & \multicolumn{3}{|c|}{ Magnesium (\%) } \\
\hline & 2008 & 2009 & 2010 & 2008 & 2009 & 2010 & 2008 & 2009 & 2010 & 2008 & 2009 & 2010 \\
\hline \multicolumn{13}{|l|}{ UTGC } \\
\hline Herbicide & $\mathrm{nc}^{\mathrm{b}}$ & 1.18 & $0.92 \mathrm{a}$ & $\mathrm{nc}$ & 0.30 & 0.23 & nc & 2.49 & $2.60 \mathrm{~b}$ & $\mathrm{nc}$ & 0.33 & 0.33 \\
\hline UTCC & nc & 0.97 & $0.87 \mathrm{~b}$ & $\mathrm{nc}$ & 0.19 & 0.20 & $\mathrm{nc}$ & 2.85 & $3.03 \mathrm{a}$ & $\mathrm{nc}$ & 0.26 & 0.30 \\
\hline \multicolumn{13}{|l|}{ Rootstock } \\
\hline $101-14$ & $\mathrm{nc}$ & 1.10 & $0.94 \mathrm{a}$ & nc & 0.24 & $0.20 \mathrm{~b}$ & nc & $3.04 \mathrm{a}$ & $3.56 \mathrm{a}$ & $\mathrm{nc}$ & 0.34 & $0.37 \mathrm{a}$ \\
\hline $420 \mathrm{~A}$ & $\mathrm{nc}$ & 1.02 & $0.87 \mathrm{~b}$ & $\mathrm{nc}$ & 0.29 & $0.28 \mathrm{a}$ & nc & $1.87 \mathrm{~b}$ & $1.77 \mathrm{c}$ & nc & 0.30 & $0.33 \mathrm{a}$ \\
\hline Riparia & $\mathrm{nc}$ & 1.10 & $0.88 \mathrm{~b}$ & nc & 0.20 & $0.18 \mathrm{~b}$ & nc & $3.10 \mathrm{a}$ & $3.11 \mathrm{~b}$ & $\mathrm{nc}$ & 0.24 & $0.24 \mathrm{~b}$ \\
\hline \multicolumn{13}{|l|}{$\mathbf{R M}$} \\
\hline NRR & 0.56 & 1.10 & 0.89 & 0.08 & $0.35 \mathrm{a}$ & $0.31 \mathrm{a}$ & 4.14 & 2.60 & 2.83 & 0.29 & 0.32 & $0.36 \mathrm{a}$ \\
\hline $\mathrm{RR}$ & 0.62 & 1.05 & 0.91 & 0.11 & $0.14 \mathrm{~b}$ & $0.12 \mathrm{~b}$ & 3.23 & 2.74 & 2.80 & 0.31 & 0.27 & $0.27 \mathrm{~b}$ \\
\hline \multicolumn{13}{|l|}{ Significance $^{c}$} \\
\hline UTGC & & ns & 0.0009 & & ns & ns & & ns & 0.0011 & & ns & ns \\
\hline $\mathrm{RS}$ & & ns & 0.0004 & & ns & $<0.0001$ & & 0.0144 & $<0.0001$ & & 0.0281 & $<0.0001$ \\
\hline RS $x$ UTGC & & ns & 0.0011 & & ns & ns & & ns & ns & & ns & ns \\
\hline $\mathrm{RM}$ & & ns & ns & & 0.0462 & $<0.0001$ & & ns & ns & & ns & $<0.0001$ \\
\hline RM x UTGC & & ns & 0.0005 & & 0.0042 & ns & & 0.0335 & 0.0188 & & 0.0096 & ns \\
\hline$R M \times U T G C \times R S$ & & ns & 0.0056 & & ns & ns & & ns & ns & & ns & ns \\
\hline
\end{tabular}

aUTGC: under-trellis groundcover; UTCC: under-trellis cover crop; RM: root manipulation; NRR: non-root restricted; RR: root restricted; RS: rootstock.

${ }^{b} \mathrm{nc}$ : treatments not compared in 2008. Means within treatment effect and column that are followed by the same letter do not differ at $p \leq 0.05$. 'Significance of treatment effects and interactions ( $p>F$; ns = not significant). 
allow for more in-depth questions about how vine capacity, leaf area to crop ratios, and duration of vegetative growth impact fruit composition and wine sensory properties. Commercially, the cost of bags and the added labor of installation as well as the more stringent irrigation management required would have to be considered over the lifespan of the vineyard to determine whether the additional costs could be recouped via reduced canopy management and potentially improved wine quality.

Carbon isotope discrimination analysis offered further evidence of the chronic effects of root restriction on limiting water uptake by $\mathrm{RR}$ vines. The $\delta^{13} \mathrm{C}$ values reported here are similar to those determined in studies where water availability to grapevines was regulated to impose a range of water stress (Chaves et al. 2007, de Souza et al. 2005) or where natural soil types afforded a range of plant available water levels (Van Leeuwen et al. 2009). While RR caused a pronounced reduction in the discrimination against ${ }^{13} \mathrm{C}$, UTCC did not. Our $\delta^{13} \mathrm{C}$ values of -24 to -24.4 for berry juice of $\mathrm{RR}$ vines corresponded to minimal $\psi_{\text {stem }}$ values of $-0.9 \mathrm{MPa}$ (Figure 8), which is consistent with the provisional threshold of "moderate to weak water deficit" suggested elsewhere (Van Leeuwen et al. 2009). The $>3.00$ per mil difference in $\delta^{13} \mathrm{C}$ observed between juice of RR and NRR vines is a relatively large treatment separation compared to published studies with grape (Gómez-Alonso and García-Romero 2010). As did other studies (Chaves et al. 2007, de Souza et al. 2005), we found greater amplitude of treatment effects on $\delta^{13} \mathrm{C}$ with berry juice than with leaf laminae. In the latter case, the midshoot leaves that we sampled had fully developed by bloom and their structural carbon was essentially fixed at that point. Differences in $\delta^{13} \mathrm{C}$ at the time of sampling would reflect both the structural carbon and the nonstructural carbohydrates present in the leaf at sampling. As such, the leaf carbon isotope record reflects contributions from the stored reserves of the previous season as well as structural and nonstructural carbon compounds assimilated during the current season.

Reductions in vine vegetative growth and crop yields have occurred where interrow (Celette et al. 2005, Tan and Crabtree 1990, Volaire and Lelièvre 2010) and complete vineyard floor cover cropping (Tesic et al. 2007) have been used. The evidence here, in particular the $\psi_{\text {stem }}$ and gas exchange data, suggest that competition with water was the primary cause of the reduced seasonal, vegetative growth observed with UTCC. The under-trellis soil moisture data, however, provide somewhat equivocal support of this effect. The consistent (over three seasons) pattern of lower soil moisture content under UTCC at $600 \mathrm{~mm}$ soil depth might be interpreted as greater cover crop use of moisture from this depth, relative to the herbicide strip floor management, as has been observed under Mediterranean conditions (Celette et al. 2005, Volaire and Lelièvre 2010). The majority of fescue roots, and hence soil water uptake, occur within the top $0.5 \mathrm{~m}$ of the soil surface (Celette et al. 2005). An alternative interpretation of treatment differences in soil moisture at $600 \mathrm{~mm}$ is that the presence of grass roots within the top $0.5 \mathrm{~m}$ profile of soil resulted in a deeper development of fine grapevine roots, as observed in similar studies (Celette et al. 2005), and it was primarily the grapevines that were transpiring the soil moisture at $600 \mathrm{~mm}$. That might explain why the treatment differences persisted all season, even when the cool-season fescue entered a relatively dormant period of summer. In either case, the more stable and nonsignificant treatment effects observed at $1000 \mathrm{~mm}$ could potentially be interpreted as evidence that neither the UTCC nor the grapevines were withdrawing moisture differentially at that depth. It is more difficult to explain the seasonal patterns of soil moisture content in the 100 to $400 \mathrm{~mm}$ strata, where we observed inconsistent and generally insignificant treatment effects on soil moisture levels over several years. More detailed soil moisture monitoring and root development studies, while beyond the scope of this report, could shed light on how UTCC affects the infiltration and retention of soil moisture and the potential to influence the ability of the vines to exploit soil moisture.

Although vine water status appeared to be altered by UTCC, the effects were not as dramatic as with root restriction. Responses such as shoot growth rates, canopy density, and cane pruning weights were also affected by UTCC and may have been due to factors other than simply the vine water status. Interrow tall fescue ( $F$. arundinacea) reduced vine vegetative growth, but had little or no impact on predawn leaf water potential or midday stomatal conductance (Celette et al. 2005). The authors argued, justifiably, that consideration be given to the full range of factors that may account for growth and developmental effects. We noted that UTCC was associated with lower rates of shoot growth than were measured with herbicide plots (Table 1) in the period from 22 May to 19 June, and yet $\psi_{\text {stem }}$ did not differ between those treatments during that period. It is possible that lower-thanoptimal ( $\sim 0.60 \%)$ nitrogen levels in vines during 2008 contributed to growth effects observed in both 2008 and 2009. Interrow sod will compete with vines for $\mathrm{N}$, reducing $\mathrm{N}$ concentration and shoot growth of the companion vines (Tan and Crabtree 1990). In arid environments, the reduction in vine $\mathrm{N}$ by companion cover crops can be due to direct use of soil $\mathrm{N}$ by the cover crops and to reduced mineralization of $\mathrm{N}$ that occurs as soil moisture is depleted by the cover crop (Celette et al. 2009). The latter could be an important factor given the very low organic matter ( 0.8 to $1.8 \%$ ) in our vineyard at the onset of the experiment. Other potentially limiting factors to explain the growth reduction caused by UTCC include reduced availability of other nutrients, root-to-shoot hormone signaling, and possibly allelopathic effects of the grass sward. While allelopathy is often mentioned as a potential consequence of growing grapevines with a companion grass, such as Festuca, evidence to support this response is not readily available.

Although reduced $\mathrm{N}$ availability to vines with UTCC may have contributed to reduced growth with UTCC treatment, we do not believe that differential $\mathrm{N}$ levels in the tissue solely explain treatment effects. Nitrogen levels were not significantly different between treatments at bloom in 2009 and differences in shoot growth rate persisted into 2010. With the exception of $\mathrm{P}, \mathrm{K}$, and $\mathrm{Mg}$, other petiole levels of nutrients were not 
affected by treatment. Phosphorus levels were lower than optimal in 2008 and remained depressed in the RR vines, relative to NRR vines in 2009; however, P levels were generally above the minimum optimal range (Bates and Wolf 2008) for bloom-sampled vines, suggesting that $\mathrm{P}$ was not a limiting factor. Similarly, although 420A was associated with reduced $\mathrm{K}$ uptake, and Riparia was associated with reduced $\mathrm{Mg}$ uptake, the depressed levels of those nutrients were not considered deficient. The relatively depressed uptake of $\mathrm{K}$ by vines grafted to $420 \mathrm{~A}$ ( $V$. berlandieri $\mathrm{x} V$. riparia) has been reported for a range of cultivars grafted to 420A rootstock, including Cabernet Sauvignon (Wolpert et al. 2005).

Vines grafted to the rootstock Riparia had reduced vegetative growth compared to vines grafted to 420A and 101-14 in this trial. Riparia is well known to reduce vegetative components of scion growth (Pongracz 1983). We find it interesting that the relative scion "vigor" conferred by Riparia, 420A, and 101-14 under field conditions (e.g., Pongracz 1983) was retained even under the substantially confined environment of the root-restrictive bags used here. Whether measured by annual cane pruning weights, trunk circumference, or shoot growth rates, vines grafted to Riparia exhibited somewhat weaker growth than observed with the other two rootstocks whether root growth was restricted or not. This suggests that the biophysical (e.g., hydraulic resistance) or biochemical (e.g., hormone) contributions of the roots to the aerial growth of the vines are potentially as important as the morphological adaptations of the root system to soil conditions.

The additive, vine size depressive effects of RR and UTCC resulted in cane pruning weights that were less than 0.30 $\mathrm{kg} / \mathrm{m}$ of canopy, the lower threshold for a provisional, "optimal" vine size range (Smart and Robinson 1991). Conversely, the NRR vines grown with herbicide strips trended at or above the upper threshold for that range and most were above even the more generous vine size range suggested elsewhere (Dokoozlian and Kliewer 1995). The benefits of suppressed vegetative canopy development - when vine size and vigor are excessive - are manifold. Humid region winegrape producers expend considerable labor on remedial canopy management practices to remove shading or otherwise superfluous vegetation. "Leaf thinning" from the fruit zone, for example, often entails the combined removal of up to several primary leaves and, with vigorous vines, three or more lateral shoots from the first 10 nodes of the primary shoot. The improved radiation environment and ventilation afforded by these practices reduces bunch rot incidence (Zoecklein et al. 1992) and powdery mildew infestation (Austin et al. 2011) and is generally considered to improve wine quality potential (Smart et al. 1985). In addition to reducing the need for shoot hedging, UTCC, RR, or their combination substantially reduced lateral shoot development within the canopy fruit zone and the need for repeated shoot hedging with VSP-trained canopies. Perennial grass groundcover also reduced lateral leaf development at a vineyard site that had a rooting depth of 1 m (Pieri et al. 1999); a parallel groundcover experiment at a site with rooting depth of $\geq 2 \mathrm{~m}$ did not translate to differences in lateral leaf area. It is uncertain whether the UTCC floor-management system used in our study would elicit the same effects on vine size and canopy characteristics under different vineyard conditions. The soil at our experimental site had a relatively low water-holding capacity, low organic matter content, and a relatively shallow rooting depth, all of which could have increased the competitive effects of UTCC with grapevines. We have observed more subtle effects of UTCCs in a similar climate when vines are grown on deeper soils with greater water-holding capacities (Giese and Wolf 2009). Thus, in addition to climatic influences and the species of cover crop used, the benefits of companion cover crops on canopy architecture and management may also be modified by soil conditions. Perennial intrarow cover crops are not compatible with the annual hilling and dehilling of graft unions for protection of cold-tender grapevines. This imposes limitations on how intrarow or under-trellis perennial cover crops could be used in regions that experience potentially damaging low temperature events. The UTCC also complicates certain other cultural practices, such as nitrogen nutrition of vines, although fertilization practices can be adapted to meet vine needs without simply benefiting the cover crop (Celette et al. 2009).

\section{Conclusion}

Results have demonstrated that it is possible to regulate vine size, vigor and, by extension, vine capacity in a mesic environment. The cascading treatment effects of UTCC, size-limiting rootstock, and root restriction afforded a novel system to explore a range of vigor and vine-size regulating treatments. The applied benefits of these techniques could be reduced canopy management labor and improved fruitzone exposure. Our longer-term goal, however, is to better understand the relationships between vine capacity and fruit and wine quality attributes under humid growing conditions, where it is often difficult to separate the effects of vigor, duration of vegetative development, and vine capacity. Suppression of vegetative growth with root restriction was likely principally due to water deficit; however, root restriction could also have reduced nitrogen and carbohydrate reserves and could possibly have led to root-to-shoot hormonal signals in response to the altered root environment. Intrarow cover crop also reduced vine vegetative development, a response likely due to more than simply competition with vines for moisture. Rootstock also affected vine development, particularly cane pruning weights, at least in the first five years of the vineyard.

\section{Literature Cited}

Austin, C.N., G.G. Grove, and W.F. Wilcox. 2011. Powdery mildew severity as a function of canopy density: Associated impacts on sunlight penetration and spray coverage. Am. J. Enol. Vitic. 62:23-31.

Bates, T.R., and T.K. Wolf. 2008. Nutrient management. In Wine Grape Production Guide for Eastern North America. T.K. Wolf (ed.), pp. 141-168. Natural Resource, Agriculture, and Engineering Service, Ithaca, NY.

Boland, A.M., P.H. Jerie, P.D. Mitchell, I. Goodwin, and D.J. Connor. 2000. Long-term effects of restricted root volume and regulated deficit irrigation on peach: II. Productivity and water use. J. Amer. Soc. Hort. Sci. 125:143-148. 
Byers, R.E., D.H. Carbaugh, and L.D. Combs. 2005. Root restriction, an alternative to roostocks, for control of flowering, fruiting, tree growth, yield efficiency, and fruit quality of apple. J. Tree Fruit Production 3:11-31.

Caspari, H.W., S. Neal, and A. Naylor. 1997. Cover crop management in vineyards to enhance deficit irrigation in a humid climate. In Second International Symposium on Irrigation of Horticultural Crops. K.S. Chartzoulakis and A.N. Angelakis (eds.). ISHS Acta Hortic. 449:313-320.

Celette, F., J. Wery, E. Chantelot, J. Celette, and C. Gary. 2005. Belowground interactions in a vine (Vitis vinifera L.)-tall fescue (Festuca arundinacea Shreb.) intercropping system: Water relations and growth. Plant Soil 276:205-217.

Celette, F., R. Gaudin, and C. Gary. 2008. Spatial and temporal changes to the water regime of a Mediterranean vineyard due to the adoption of cover cropping. Eur. J. Agron. 29:153-162.

Celette, F., A. Findeling, and C. Gary. 2009. Competition for nitrogen in an unfertilized intercropping system: The case of an association of grapevine and grass cover in a Mediterranean climate. Eur. J. Agron. 30:41-51.

Chaves, M.M., T.P. Santos, C.R. Souza, M.F. Ortuño, M.L. Rodrigues, C.M. Lopes, J.P. Maroco, and J.S. Pereira. 2007. Deficit irrigation in grapevine improves water-use efficiency while controlling vigour and production quality. Ann. Appl. Biol. 150:237-252.

de Souza, C.R., J.P. Maroco, T.P. dos Santos, M.L. Rodrigues, C.M. Lopes, J.S. Pererra, and M.M. Chaves. 2005. Impact of deficit irrigation on water use efficiency and carbon isotope composition $\left(\delta^{13} \mathrm{C}\right)$ of field-grown grapevines under Mediterranean climate. J. Expt. Bot. 56:2163-2172.

Dokoozlian, N.K., and W.M. Kliewer. 1995. The light environment within grapevine canopies. II. Influence of leaf area density on fruit zone light environment and some canopy assessment parameters. Am. J. Enol. Vitic. 46:219-226.

Dry, P.R., and B.R. Loveys. 1998. Factors influencing grapevine vigour and the potential for control with partial rootzone drying. Aust. J. Grape Wine Res. 4:140-148.

Giese, G., and T.K. Wolf. 2009. Root pruning and groundcover to optimize vine vigor and berry composition in Cabernet Sauvignon grapevines. Abstr. Am. J. Enol. Vitic. 60:551A.

Gómez-Alonso, S., and E. García-Romero. 2010. Effect of irrigation and variety on oxygen $\left(\delta^{18} \mathrm{O}\right)$ and carbon $\left(\delta^{13} \mathrm{C}\right)$ stable isotope composition of grapes cultivated in a warm climate. Aust. J. Grape Wine Res. 16:283-289.

Ingels, C.A., K.M. Scow, D.A. Whisson, and R.E. Drenovsky. 2005. Effects of cover crops on grapevines, yield, juice composition, soil microbial ecology, and gopher activity. Am. J. Enol. Vitic. 56:19-29.

Jensen, K.B., K.H. Asay, D.A Johnson, and B.L. Waldron. 2002. Carbon isotope discrimination in orchardgrass and ryegrasses at four irrigation levels. Crop Sci. 42:1498-1503.

Kliewer, W.M., and N.K. Dokoozlian. 2005. Leaf area/crop weight ratios of grapevines: Influence on fruit composition and wine quality. Am. J. Enol. Vitic. 56:170-181.

Matthews, M.A., M.M. Anderson, and H.R. Schultz. 1987. Phenologic and growth responses to early and late season water deficits in Cabernet franc. Vitis 26:147-160.

McArtney, S.J., and D.C. Ferree. 1999. Root and cane pruning affect vegetative development, fruiting, and dry-matter accumulation of grapevines. HortScience 34:617-621.
Meyers, J.M., and J.E. Vanden Heuvel. 2008. Enhancing the precision and spatial acuity of point quadrat analyses via calibrated exposure mapping. Am. J. Enol. Vitic. 59:425-431.

Naor, A., and R.L. Wample. 1994. Gas exchange and water relations of field-grown Concord (Vitis labruscana Bailey) grapevines. Am. J. Enol. Vitic. 45:333-337.

NRCS (Natural Resource Conservation Service). 1987. US Geological Survey, Frederick County, Virginia (http://websoilsurvey.nrcs. usda.gov).

Pieri P., C. Riou, and C. Dubois. 1999. Competitions for nitrogen and water in two vine-grass systems-Application of a water balance model. Acta Hortic. 493:89-96.

Pongracz, D.P. 1983. Rootstocks for Grapevines. David Phillip, Cape Town.

Smart, R.E., and M.D. Robinson. 1991. Sunlight into Wine: A Handbook for Winegrape Canopy Management. Winetitles, Adelaide.

Smart, R.E., J.B. Robinson, G.R. Due, and C.J. Brien. 1985. Canopy microclimate modification for the cultivar Shiraz II. Effects on must and wine composition. Vitis 24:119-128.

Tan, S., and G.D. Crabtree. 1990. Competition between perennial ryegrass sod and 'Chardonnay' wine grapes for mineral nutrients. HortScience 25:533-535.

Tesic, D., M. Keller, and R.J. Hutton. 2007. Influence of vineyard floor management practices on grapevine vegetative growth, yield, and fruit composition. Am. J. Enol. Vitic. 58:1-11.

Van Leeuwen, C., and G. Seguin. 1994. Incidences de l'alimentation en eau de la vigne, appréciée par l'état hydrigue du feuillage, sur le développement de l'appariel vegetative et la maturation du raisin. J. Int. Sci. Vigne Vin 28:81-110.

Van Leeuwen, C., O. Tregoat, X. Choné, B. Bois, D. Pernet, and J.P. Gaudillère. 2009. Vine water status is a key factor in grape ripening and vintage quality for red Bordeaux wine. How can it be assessed for vineyard management purposes? J. Int. Sci. Vigne Vin 43:121-134.

Volaire, F., and F. Lelièvre. 2010. Role of summer dormant perennial grasses as intercrops in rainfed Mediterranean vineyards. Crop Sci. 50:2046-2054.

Wang, S., G. Okamoto, K. Hirano, J. Lu, and C. Zhang. 2001. Effects of restricted rooting volume on vine growth and berry development of Kyoho grapevines. Am. J. Enol. Vitic. 52:248-253.

Wheeler, S.J., A.S. Black, and G.J. Pickering. 2005. Vineyard floor management improves wine quality in highly vigorous Vitis vinifera 'Cabernet Sauvignon' in New Zealand. N.Z. J. Crop Hortic. Sci. 33:317-328

Williams, L.E., and F.J. Araujo. 2002. Correlations among predawn leaf, midday leaf, and midday stem water potential and their correlations with other measures of soil and plant water status in Vitis vinifera. J. Amer. Soc. Hort. Sci. 127:448-454.

Wolpert, J.A., D.R. Smart, and M. Anderson. 2005. Lower petiole potassium concentration at bloom in rootstocks with Vitis berlandieri genetic backgrounds. Am. J. Enol. Vitic. 56:163-169.

Zoecklein, B.W., T.K. Wolf, N.W. Duncan, J.M. Judge, and M.K. Cook. 1992. Effects of fruit zone leaf removal on yield, fruit composition, and fruit rot incidence of Chardonnay and White Riesling (Vitis vinifera L.) grapes. Am. J. Enol. Vitic. 43:139-148. 